\title{
Colonization of Non-Traditional Range in Dispersing Elk, Cervus elaphus nelsoni, Populations
}

\author{
FRED VAN DYKE
}

Montana Department of Fish, Wildlife and Parks, Red Lodge, Montana 59068, USA

Present address: Department of Biology, Wheaton College, Wheaton, Illinois 60187 USA; e-mail: fred.g.vandyke@wheaton.edu

Van Dyke, Fred. 2007. Colonization of non-traditional range in dispersing Elk, Cervus elaphus nelsoni, populations. Canadian Field-Naturalist 121(2): 133-141.

As ungulate populations increase in density on traditional range, resulting increases in intraspecific competition can encourage dispersal of some individuals to new areas. Such areas, although lower in density of conspecifics, might present unfamiliar arrays and types of habitat that could require altered patterns of home range and habitat use by dispersers. However, the specific adaptations employed by dispersers in such circumstances are not well documented or understood. I investigated three cases of range expansion by Elk (Cervus elaphus nelsoni) populations experiencing population growth on traditional ranges in south-central Montana, USA. Each source population produced a group that dispersed to non-traditional areas. Compared to source populations, dispersing groups increased average size of home ranges, changed patterns of use in core areas of home ranges, and used habitats differently than Elk on traditional range. Dispersing groups demonstrated fidelity to new ranges equal to that of source populations, but their seasonal tenure on non-traditional range was strongly linked to environmental conditions, especially rainfall. Dispersal of groups increased the overall range of the population and its range of habitat use. In growing populations of Elk, managers should determine if dispersing groups exist and whether they should be protected to establish new populations in marginal areas or be reduced to limit potential Elk-landowner conflicts.

Key Words: Elk, Cervus elaphus, dispersal, habitat use, population, Montana.

On traditional ranges, animals typically concentrate use in the most productive patches of habitat (Charnov 1976; Parker and Stuart 1976). However, intraspecific population pressure, often associated with population growth, can cause a species to increase its range of habitat use in less predictable ways (Rosenzweig 1991). For non-territorial species, the tendency to increase range of habitat use with increasing population density has been formalized as the Ideal Free Distribution (IFD) Theorem. The Ideal Free Distribution Theorem asserts that individuals choose habitats at densities associated with equal levels of fitness (Fretwell and Lucas 1970). Thus, IFD predicts that when populations occupy new ranges at low densities, individuals will occupy only optimal habitat. As density increases, so does interference with conspecifics, causing individual fitness to decline. Individuals leave optimal habitat when fitness drops below what they could achieve in a suboptimal habitat at a lower population density.

Among ungulates, the behavior of Elk (Cervus elaphus nelsoni) in populations experiencing long-term population growth corresponds to predictions of IFD. Dispersive behavior associated with population growth and an increasing range of habitat use might contribute to the initial stages of colonization and the establishment of a permanent population in a previously unoccupied area (Safriel and Ritte 1983). The colonization of vacant habitat without decreased fitness of colonists is an alternative to increased intraspecific competition on traditional range. Although the IFD Theorem makes density-dependent dispersal theoretically plausible, such dispersal has been difficult to demonstrate in ungulates (Clutton-Brock et al. 1985; Boyce 1989), and determination of the mechanisms of colonization by individuals dispersing from established ungulate populations, or their relation to population growth, has been problematic.

In three increasing populations in south-central Montana, USA, Elk demonstrated changes in habitat use and home-range characteristics, increasing spatial separation of adjacent populations, and fissioning of individual populations into multiple populations (Van Dyke and Klein 1996; Van Dyke et al. 1998), all of which can lead to an increasing range of habitat use. The last response, population fissioning, was initiated by the formation of a dispersing group that made seasonal movements to new range, often containing a distribution of vegetation communities different from the traditional range of the established population. In investigating the role of such groups in expanding range and habitat use of established populations, I sought to determine what changes dispersing Elk make in their use of home range and habitats compared to their populations of origin that might enable them to persist on new ranges that the established population did not use.

\section{Study Area}

Three populations of Elk in south-central Montana (USA) were investigated, locally known as the Line Creek (LC), Picket Pin (PP), and Silver Run (SR) populations (Van Dyke and Klein 1996; Van Dyke et al. 1998). 
These populations summer in the Absaroka-Beartooth Wilderness Area and winter in lower elevation foothills and prairies on the Custer National Forest and adjoining private land (Figure 1).

Climate in this area was characterized by long, cold winters and short, cool summers during the study period. Mean January and July temperatures at the Mystic Lake, Montana, reporting station (elevation $2339 \mathrm{~m}$ ) near the approximate center of the study area were -4.1 and $17.1^{\circ} \mathrm{C}$, respectively. Average annual rainfall and snowfall reported at the same location were 64.7 and $497.9 \mathrm{~cm}$, respectively (NOAA 1992).

Forests were dominated, from lowest to highest elevations, by Limberpine (Pinus flexilis), Lodgepole Pine (P. contorta), Douglas Fir (Pseudotsuga menziesii), Engelmann Spruce (Picea engelmannii), and Whitebarked Pine (Pinus albicaulis). Non-forested communities at lower elevations were dominated by Bunchgrass (Pseudoroegneria spicata)-forb and sagebrush (Artemisia spp.) associations. Alpine areas were dominated by sedges (Carex spp.), cottongrass (Eriophorum spp.), Alpine Bluegrass (Poa alpina), and various alpine forbs. Detailed descriptions of these plant communities are provided in Van Dyke et al. (1991) and Van Dyke et al. (1994).

\section{Methods}

Sampling Procedures

Thirty-five female Elk were captured and radiocollared in January-March 1988 (19), December and February 1989 (11), March 1990 (1), and March 1991 (4). All but three were captured by darting from a helicopter (Nielson and Shaw 1967) with Carfentanil (dosage $0.0082 \mathrm{mg} / \mathrm{kg}$ ). Two Elk were captured in baited traps and one Elk by a net-gun fired from a helicopter. All were fitted with telemetry collars (AVM Instrument Co., Telonics, Inc.). Procedures associated with locating individual animals have been described (Van Dyke and Klein 1996; Van Dyke et al. 1998).

\section{Detection of Dispersing Groups}

I documented movements of small groups $(\leq 40$ individuals) away from source populations (120-160 individuals) through relocations of $\geq 1$ radio-collared Elk in each group. Such groups used different ranges and remained isolated from individuals in the source populations for 6-9 months each year. One group separated from each source population. These were the Trout Creek (TC) group from the PP population, the Hellroaring (HR) group from the SR population, and the Wolf Creek (WC) group from the LC population.

The relationship of dispersing groups to source populations, as well as the boundaries of seasonal ranges of the dispersing groups, was unknown prior to the study. As a result, individuals in dispersing groups were unintentionally collared when they were near source populations on winter range. Although only a small number of Elk were radio-collared in each group, the percentages of radio-collared Elk in such groups were $\geq$ those collared in source populations $(5-12 \%$ vs. 4 $6 \%$, respectively). Given the sociability of Elk, previous studies have been successful in tracking large groups even when only one radio-collared animal was present (e.g., Craighead et al. 1973), and that also was the case in this study. Locations of radio-collared individuals were considered representative of the entire group because: (1) dispersing groups contained few (7-40) individuals; (2) dispersing groups remained constant in size during occupancy on non-traditional range, indicating that groups possessed a high degree of cohesiveness; and (3) radio-collared individuals always were present in the group when they were located.

\section{Estimation and Analysis of Home Range Characteristics}

Home range of each population or group was defined as the $95 \%$ contour minimum convex polygon (MCP) area and associated activity centers of source populations and dispersing groups as computed by HOME RANGE, a home range analysis program (Ackerman et al. 1990). To estimate seasonal home ranges, seasons were defined as winter-spring (1 December - 31 May) and summer-autumn (1 June - 30 November). Seasons were combined in this manner because source populations had substantial overlap between winter and spring ranges and between summer and autumn ranges (Van Dyke and Klein 1996; Van Dyke et al. 1998).

Because MCPs are sensitive to sample size, I evaluated only populations with $\geq 21$ locations/season for calculation of seasonal range and $\geq 45$ total locations for calculation of annual range. All samples were equal to or larger (seasonal $\bar{x}=97$, range 21-438; annual $\bar{x}=189$, range 45-787) than these minimums. Previous tests of the relation between numbers of locations and home area estimates indicate that such sample sizes estimated $\geq 81 \%$ of population home ranges for ungulates in this area (Van Dyke et al. 1995; Van Dyke et al. 1998). Core areas within home ranges (Kaufman 1962) were identified by comparing actual range use distributions generated from harmonic mean estimates of home range (Dixon and Chapman 1980) to hypothetical uniform use distributions (Samuel et al. 1985). I also determined the percent contribution of core areas to total home areas and core area percent contribution to total use, and then determined the ratio of use contribution to area contribution as an index of the concentration of use in core areas.

\section{Evaluation of Range Use}

Home areas of dispersing groups and source populations were compared in four ways. First, as a first approximation of potential movement differences in landscape pattern and scale, I compared distances Elk in dispersing groups moved from winter to spring or summer ranges with the same movements in their associated traditional populations using linear, straightline distances between seasonal geometric activity centers in each group as determined by pooled locations from 1988-1992. I compared distances associ- 


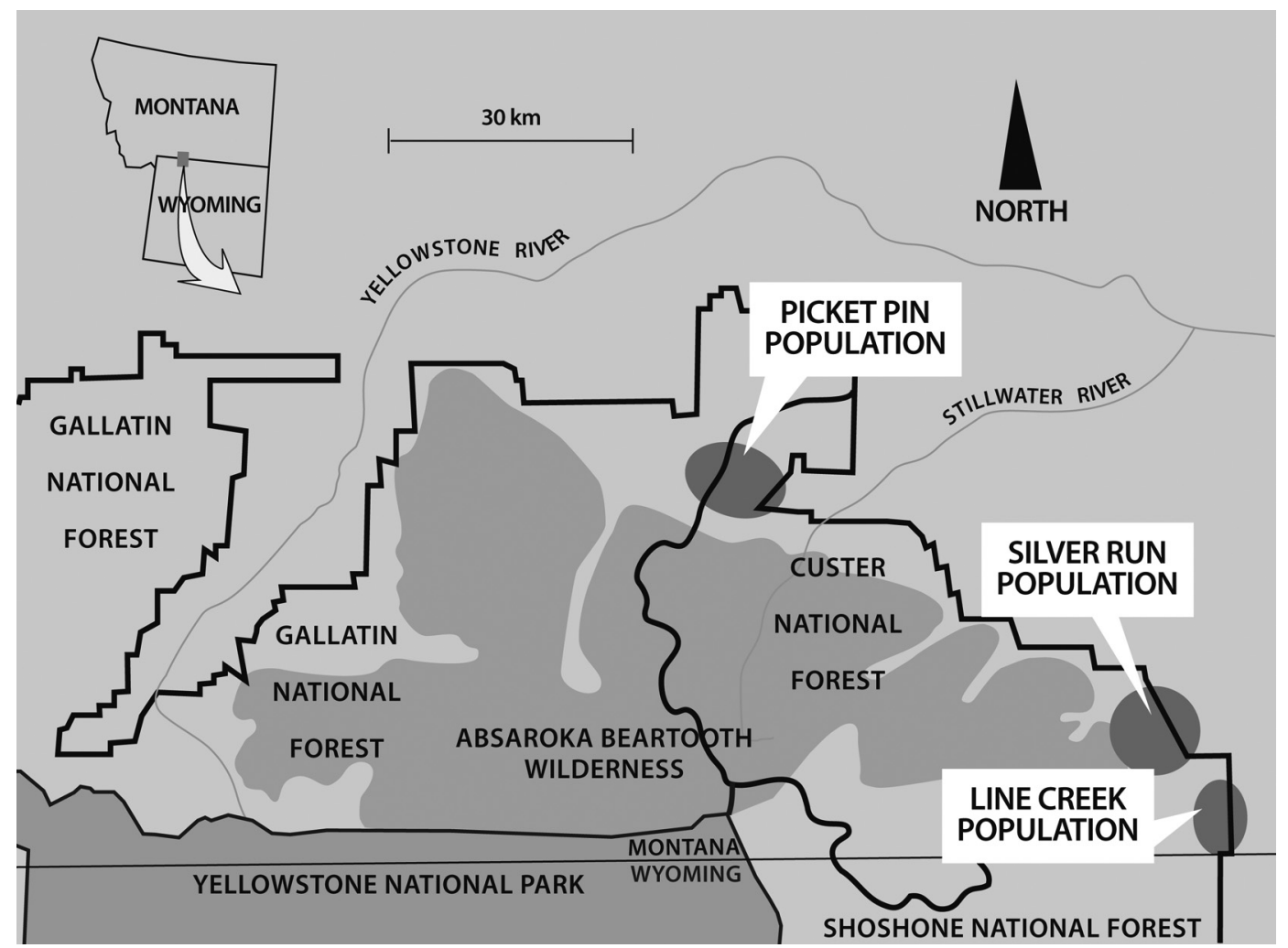

FIGURE 1. Study area and approximate ranges of the Line Creek, Picket Pin, and Silver Run populations of Elk in south-central Montana, USA, 1988-1991.

ated with such movements to the radius of the shared winter home area as an index of relative movement scale. Second, I compared home range size between source populations and dispersing groups using 2sample $t$-tests. Third, I evaluated Euclidean distances between points in associated dispersing group and source populations through a multiple range permutation procedures test, which evaluates whether distributions of distances in different groups come from a common probability distribution (Mielke et al. 1976). Fourth, I compared use-area ratios of core areas between dispersing groups and associated source populations to determine if differences existed in degree of concentration of core area use using a 2-sample $t$-test. The ratio of core to non-core use is important because core areas would be likely to include the most optimal habitat within a home range. Therefore I treated the concentration of use in core areas as an index of relative differences between optimal and suboptimal habitats within a home range.

\section{Use of Vegetation Communities and Production of Forage}

The types of vegetation communities present on all seasonal ranges of all populations varied, but were simplified for analysis to categories of alpine, grass- forb (meadows), Douglas Fir, Limberpine, Lodgepole Pine, sagebrush, Spruce (subalpine forest), and Whitebark Pine. Together, these vegetation communities covered the range of elevations used by all populations in all seasons as well as broadly covering the array of vegetation communities encountered and used by Elk. Comparisons of use of vegetation communities by Elk in source populations, based on locations of animals, to availability of such communities visually identified at 568 randomly selected points within home areas of such populations were evaluated using the Design I version of Manly et al. (2002) resource selection function (RSF) model. This version of the RSF model, which uses independently sampled counts of available and used resources, assumes that the availability of vegetation communities does not change over the course of the study period, that vegetation communities were correctly identified, and that Elk had free and equal access to all vegetation communities within their designated ranges, assumptions that were met in this study. The model's null hypothesis that Elk select vegetation communities in proportion to their occurrence was tested by comparing use to availability via a Chi-square goodness of fit test (Manly et al. 2002). The application of this procedure to similar tests for random selection of 
each vegetation community was adjusted using Bonferroni corrections to prevent error accumulation. I used Manly's standardized selection ratio to represent relative strength of selection for a given vegetation community. Vegetation communities with 0 availability in a given range were omitted from analysis.

Locations of Elk during 1988-1991 were used to determine core foraging areas of dispersing groups on summer ranges. Using radio telemetry locations and visual observation, I established five $404-\mathrm{m}^{2}$ $(20.1 \mathrm{~m} \times 20.1 \mathrm{~m})$ macroplots selected within core foraging areas determined in each dispersing group and in the core foraging area of the PP population in 1991. Ten macroplots already had been established in core foraging areas of LC and SR populations (five in each area) as part of another study (Van Dyke et al. 1994). I compared volumes of forbs and graminoids produced from each core area associated with dispersing groups to core areas of respective source populations through 2-sample $t$-tests. Sampling methods have been described (Van Dyke et al. 1991, 1994). Shrubs were not included in the analysis because shrub coverage was low on most plots and summer diets of Elk in all populations averaged $<10 \%$ shrubs (Van Dyke et al. 1994). Although species-specific forage selection was evident (Van Dyke et al. 1994), all available graminoids and forbs were consumed. Thus, estimates of forb and graminoid volume were considered to represent volume of edible browse.

\section{Results}

Seasonal dispersal and home range characteristics

All dispersing groups moved greater absolute and relative distances from winter to spring or summer ranges than traditional populations, and, in two of three cases, traveled in entirely different directions and followed different elevational gradients (Table 1). Relative to the size of winter home areas, traditional populations migrated distances $2.3-7.5 \times$ the radius of their winter home areas to reach spring and summer ranges, but dispersing groups moved 5.6-11.0x the radius of their winter home areas to reach new, non-traditional ranges in the same seasons.

Elk in dispersing groups used annual or seasonal ranges differently than Elk in associated source populations (Table 2). Differences also existed in home range sizes of dispersing groups and source populations (Figure 2). The annual and seasonal home ranges of Elk in the TC and WC groups were larger than home ranges of Elk in associated source populations. In contrast, seasonal home ranges of Elk in the HR group were similar to those estimated for individuals in the associated source population. Differences between source and dispersing group populations also were evident in use of core areas (Figure 3). Hellroaring Elk made greater use of smaller areas (higher use/area ratios) in summer and autumn than did Elk in their source (SR) population. A similar trend was evident in the more concentrated use of winter and spring core areas by the WC group. In contrast, the TC group demonstrated more dispersed range use than its source (PP) population, and had no identifiable core area in winter-spring (use/area ratio $=1$ ).

\section{Patterns of habitat and elevation use in source populations: Comparisons of source populations and dispersing groups}

No population showed random proportional selection of vegetation communities $(P<0.001$, all cases), but selection patterns differed in different populations, and, in two of three cases, patterns of selection in source populations differed from selection patterns in associated dispersing groups. The SR source population and HR dispersing group were the only source population-dispersing group pair in which selection of vegetation communities did not differ. Both used alpine areas less frequently than expected and used Lodgepole Pine communities more than expected (Table 3 ). The Line Creek source population and its associated WC dispersing group differed in selection patterns in four of seven vegetation communities (Table 4), and the PP source population and its TC dispersing group in four of eight (Table 5), although patterns were different in each case. Wolf Creek Elk used sagebrush communities most commonly in the spring, followed by an intensive shift to alpine communities in the summer, resulting in nearly equal rates of use in these communities over the combined period. However, WC Elk did not use any one vegetation community differently than expected, although their overall pattern of use was different from availability. In contrast, LC Elk made more equitable use of all available vegetation types, although they were most commonly located in stands of Limberpine (33\%). Line Creek Elk used grass-forb and Limberpine communities more than expected, and sagebrush and alpine communities less than expected. Actual proportional use in grasslandforb communities was identical in the two populations. Observed differences in significance in this case were attributable to differences in the number of observations in the two groups.

The majority of PP Elk locations were in grass-forb vegetation $(56 \%)$, and this population used this vegetation type and Limberpine at greater than expected frequencies. Picket Pin Elk used Lodgepole Pine less than expected. In contrast, TC Elk were most commonly located in stands of Douglas Fir (42\%). They used this vegetation community more than expected, but used spruce-dominated vegetation less than expected.

Core foraging areas of dispersing groups and source populations differed in volumes of forbs and graminoids produced (Table 6). Trout Creek core areas had higher volumes of graminoids and forbs compared to PP core areas, but differences in other comparisons displayed no consistent pattern.

Two dispersing groups, TC and WC, showed different patterns in seasonal elevational use compared to their source populations (Figure 4). Trout Creek 
TABLE 1. Scale considerations in distance, direction, and elevational differences in pairs of traditional source populations and dispersing groups of Elk in south-central Montana, U.S.A., 1988-1991. In each pair, the traditional source population is listed first. Migration distance $(\mathrm{km})$ reflects distance from shared winter range activity center to traditional source population or dispersing group spring or summer range. Home range radii estimated as square root of home range area $\left(\mathrm{km}^{2}\right)$ divided by $\pi$.

\begin{tabular}{lcccc}
\hline \hline Population & $\begin{array}{c}\text { Migration } \\
\text { distance }\end{array}$ & $\begin{array}{c}\text { Migration } \\
\text { direction }\end{array}$ & $\begin{array}{c}\text { Elevation } \\
\text { change }\end{array}$ & $\begin{array}{c}\text { Population home } \\
\text { range radius }- \text { winter }\end{array}$ \\
\hline Line Creek & 4.9 & $\mathrm{~W}$ & Higher & 2.12 \\
Wolf Creek & 11.8 & $\mathrm{NE}$ & Lower & 1.54 \\
Picket Pin & 11.6 & $\mathrm{~W}$ & Higher & \\
Trout Creek & 17.0 & $\mathrm{NE}$ & Same & 1.70 \\
Silver Run & 11.8 & $\mathrm{SW}$ & Higher & \\
Hellroaring & 14.6 & $\mathrm{SW}$ & Higher & \\
\hline \hline
\end{tabular}

TABLE 2. Results of Multiple Range Permutation Procedures analysis comparing range utilization between dispersing groups and associated source populations in south-central Montana 1988-1991. $P<0.05$ interpreted as evidence of significantly different distributions between dispersing group and associated source population. $n=$ number of Elk locations used in analysis (source population and dispersing group, respectively). Seasons selected represent periods of movement to new ranges by dispersing groups.

\begin{tabular}{llccc}
\hline \hline Population & \multicolumn{1}{c}{ Season } & $n$ & Standardized test statistic & $P$ \\
\hline Picket Pin-Trout Creek & Annual & $348 / 71$ & -102.89 & $<0.0001$ \\
Silver Run-Hellroaring & Summer-Autumn & $291 / 58$ & -46.24 & $<0.0001$ \\
Line Creek-Wolf Creek & Spring-Summer & $263 / 73$ & -10.99 & $<0.0001$ \\
\hline \hline
\end{tabular}

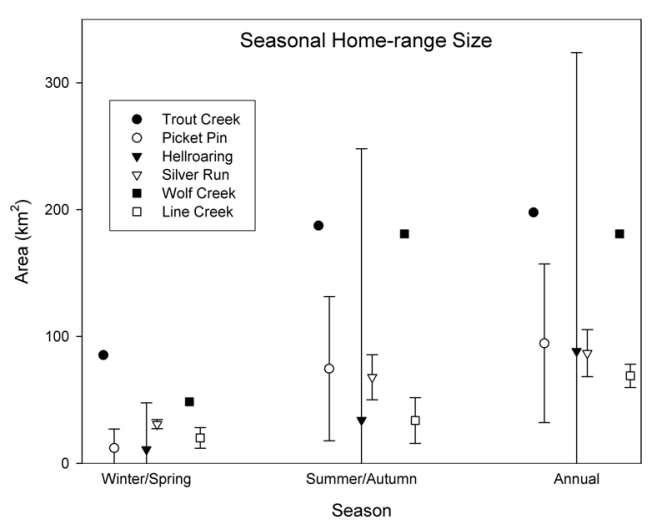

FIGURE 2. Seasonal and annual home area sizes of source populations and associated dispersing groups of Elk in south-central Montana, USA, 1988-1991. Bars indicate $95 \% \mathrm{CI}$.

Elk used lower elevations in summer $\left(t_{123}=3.62\right.$, $P<0.0001)$, consistent with their tendency to move to traditional, high elevation summer range later than PP Elk. Similarly, WC Elk used lower elevations in summer $\left(t_{212}=2.03, P=0.05\right)$ and autumn $\left(t_{157}=2.46\right.$, $P=0.02)$, reflecting their tendency to spend at least part of these periods off the Line Creek Plateau and away from the main LC population. Hellroaring Elk used elevations similar to SR Elk in all seasons, had non-overlapping ranges in summer and autumn, and

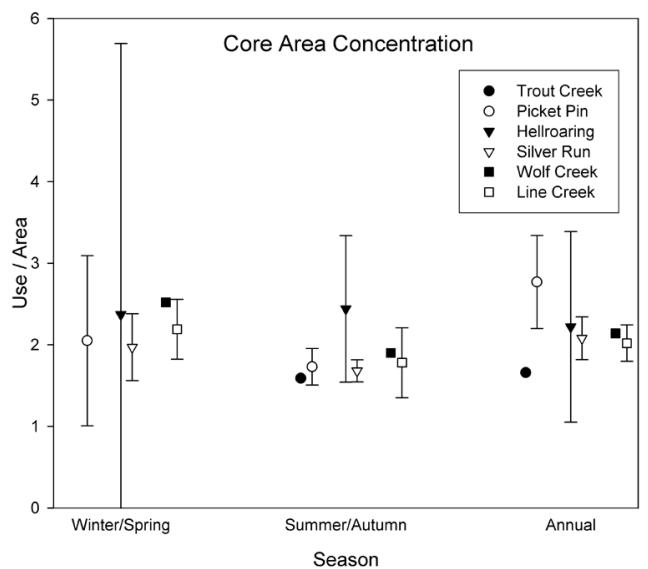

FIGURE 3. Core area concentration indices (\% use of core area/\% contribution of core area to home area) of source populations and associated dispersing groups of Elk in south-central Montana, USA, 1988-1991. Bars indicate $95 \% \mathrm{CI}$.

persisted on their new ranges throughout both seasons in all years. In contrast, TC and WC Elk always abandoned the non-traditional ranges at some point during the summer.

Over time, it became apparent that dispersing groups abandoned non-traditional ranges more quickly in drier years. I examined the strength of this relationship at the conclusion of the study through a logistic regression analysis relating June and July rainfall (estimated 
TABLE 3. Proportional availability and use of vegetation communities on summer-autumn range by the Silver Run Elk population and an associated population (Hellroaring) colonizing non-traditional range in disjunct areas in south-central Montana, USA, 1988-1991. $P$ values (Bonferroni corrected) equal the probability that proportional use equals availability.

\begin{tabular}{|c|c|c|c|c|c|c|c|}
\hline \multirow{2}{*}{$\begin{array}{l}\text { Vegetation } \\
\text { community }\end{array}$} & \multirow{2}{*}{$\begin{array}{c}\text { Proportion } \\
\text { available }\end{array}$} & \multicolumn{2}{|c|}{ Proportion used } & \multicolumn{2}{|c|}{ Standardized selection ratio } & \multicolumn{2}{|r|}{$\overline{P P}$} \\
\hline & & Silver Run & Hellroaring & Silver Run & Hellroaring & Silver Run & Hellroaring \\
\hline Alpine & 0.70 & 0.48 & 0.48 & 0.08 & 0.07 & $<0.001$ & 0.02 \\
\hline Lodgepole Pine & 0.04 & 0.22 & 0.29 & 0.60 & 0.70 & $<0.001$ & $<0.001$ \\
\hline Sagebrush & 0.08 & 0.14 & 0.12 & 0.21 & 0.16 & 0.27 & 1.00 \\
\hline Whitebark Pine & 0.18 & 0.16 & 0.11 & 0.11 & 0.07 & 1.00 & 1.00 \\
\hline
\end{tabular}

TABLE 4. Proportional availability and use of vegetation communities on spring-summer range by the Line Creek Elk population and an associated population (Wolf Creek) colonizing non-traditional range in disjunct areas in south-central Montana, USA, 1988-1991. $P$ values (Bonferroni corrected) equal the probability that proportional use equals availability.

\begin{tabular}{|c|c|c|c|c|c|c|c|}
\hline \multirow{2}{*}{$\begin{array}{l}\text { Vegetation } \\
\text { community }\end{array}$} & \multirow{2}{*}{$\begin{array}{c}\text { Proportion } \\
\text { available }\end{array}$} & \multicolumn{2}{|c|}{ Proportion used } & \multicolumn{2}{|c|}{ Standardized selection ratio } & \multicolumn{2}{|r|}{$P$} \\
\hline & & Line Creek & Wolf Creek & Line Creek & Wolf Creek & Line Creek & Wolf Creek \\
\hline Alpine & 0.33 & 0.17 & 0.39 & 0.05 & 0.16 & $<0.001$ & 1.00 \\
\hline Douglas Fir & 0.08 & 0.14 & 0.08 & 0.15 & 0.13 & 0.11 & 1.00 \\
\hline Grass-forb & 0.02 & 0.06 & 0.06 & 0.31 & 0.44 & 0.001 & 0.17 \\
\hline Limberpine & 0.10 & 0.33 & 0.07 & 0.30 & 0.09 & $<0.001$ & 1.00 \\
\hline Sagebrush & 0.30 & 0.18 & 0.40 & 0.05 & 0.18 & $<0.001$ & 0.60 \\
\hline Spruce & 0.08 & 0.09 & 0.00 & 0.04 & 0.00 & 1.00 & 0.17 \\
\hline Whitebark Pine & 0.09 & 0.04 & 0.00 & 0.10 & 0.00 & 0.21 & 0.13 \\
\hline
\end{tabular}

TABLE 5. Proportional availability and use of vegetation communities on annual range by the Picket Pin Elk population and an associated population (Trout Creek) colonizing non-traditional range in disjunct areas in south-central Montana, USA, 1988-1991. $P$ values (Bonferroni corrected) equal the probability that proportional use equals availability.

\begin{tabular}{|c|c|c|c|c|c|c|c|}
\hline \multirow{2}{*}{$\begin{array}{l}\text { Vegetation } \\
\text { community }\end{array}$} & \multirow{2}{*}{$\begin{array}{c}\text { Proportion } \\
\text { available }\end{array}$} & \multicolumn{2}{|c|}{ Proportion used } & \multicolumn{2}{|c|}{ Standardized selection ratio } & \multicolumn{2}{|r|}{$P$} \\
\hline & & Picket Pin & Trout Creek & Picket Pin & Trout Creek & Picket Pin & Trout Creek \\
\hline Alpine & 0.07 & 0.02 & 0.12 & 0.04 & 0.25 & 0.57 & 1.00 \\
\hline Douglas Fir & 0.15 & 0.13 & 0.42 & 0.11 & 0.39 & 1.00 & $<0.001$ \\
\hline Grass-forb & 0.25 & 0.56 & 0.33 & 0.28 & 0.18 & $<0.001$ & 1.00 \\
\hline Limberpine & 0.04 & 0.10 & 0.01 & 0.35 & 0.05 & 0.01 & 1.00 \\
\hline Lodgepole Pine & 0.26 & 0.05 & 0.09 & 0.02 & 0.05 & $<0.001$ & 0.06 \\
\hline Sagebrush & 0.05 & 0.02 & 0.03 & 0.06 & 0.08 & 1.00 & 1.00 \\
\hline Spruce & 0.16 & 0.11 & 0.00 & 0.09 & 0.00 & 1.00 & 0.03 \\
\hline Whitebark Pine & 0.02 & 0.01 & 0.00 & 0.05 & 0.00 & 1.00 & 1.00 \\
\hline
\end{tabular}

TABLE 6. Volume $\left(\mathrm{m}^{3} / \mathrm{ha}\right)$ of forbs and graminoids in core foraging areas of dispersing population groups and associated source populations in south-central Montana 1988-1991. $n$ (number of sampled macroplots) $=5$ except for Line Creek $(n=4)$ and Silver Run $(n=3)$. Means of plant volume in areas used by dispersing groups and areas used by source populations compared by $t$-test, same categories.

\begin{tabular}{|c|c|c|c|c|}
\hline \multirow{3}{*}{ Area } & \multicolumn{4}{|c|}{ Volume $\left(\mathrm{m}^{3} / \mathrm{ha}\right)$} \\
\hline & \multicolumn{2}{|c|}{ Forbs } & \multicolumn{2}{|c|}{ Graminoids } \\
\hline & $\mathrm{m}^{3} / \mathrm{ha}$ & $\mathrm{SE}$ & $\mathrm{m}^{3} / \mathrm{ha}$ & SE \\
\hline Trout Creek & $515^{\mathrm{a}}$ & 62 & $1218^{\mathrm{a}}$ & 230 \\
\hline Picket Pin & 228 & 32 & 307 & 22 \\
\hline Hellroaring & $318^{\mathrm{a}}$ & 11 & $326^{\mathrm{a}}$ & 84 \\
\hline Silver Run & 215 & 15 & 1002 & 376 \\
\hline Wolf Creek & $69^{a}$ & 18 & $372^{\mathrm{a}}$ & 65 \\
\hline Line Creek & 415 & 108 & 210 & 7 \\
\hline
\end{tabular}

a Different from source population. $P<0.0001$. 


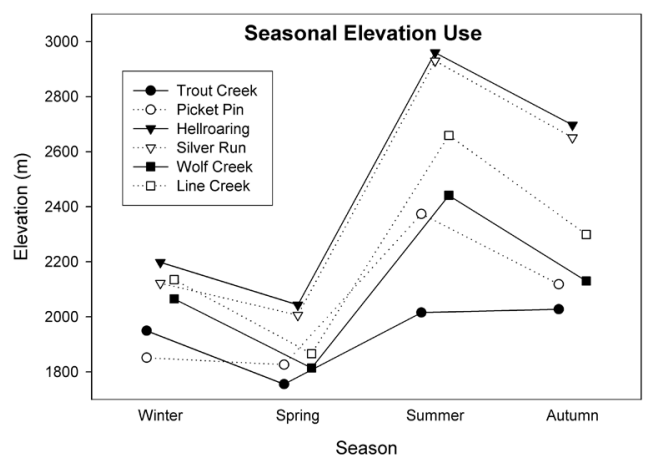

FIGURE 4. Seasonal elevational use ( $\mathrm{m}$ ) of source populations and associated dispersing groups of Elk in south-central Montana, USA, 1988-1991.

from the Red Lodge, Montana recording station for WC Elk and the Nye, Montana recording station for TC Elk, NOAA 1992) to the total estimated number of days in June, July, and August on new range. Variation in combined June and July rainfall explained two-thirds $\left(r^{2}=0.67, P<0.0001\right)$ of the variation in days on non-traditional summer range in the TC and WC groups (Figure 5).

\section{Discussion}

\section{Dispersal and density of populations}

Historical expansion and contraction of ranges of ungulate species has been influenced by many factors, both natural and anthropogenic (Laliberte and Ripple 2004), but range expansions at local levels are often achieved by dispersal, which in turn may be mediated by density (Andersen et al. 2004). An ecological correlate of a population's capacity to colonize new range is its ability to yield a large colonizing group (Safriel and Ritte 1983), something which can be best achieved during periods of population growth. In this area, annual aerial counts indicated that all source populations experienced population growth on traditional range in the decade prior to this study. From 1979 to 1988 , the PP population increased from 44 to 190 individuals (355\%), the SR population from 72 to 139 individuals (93\%), and the LC population from 85 to 127 individuals (49\%) (Van Dyke et al. 1998), and all populations continued to increase through 1991. These increases are small relative to fluctuations in historically large populations of Elk like the nearby Northern Yellowstone Population which has ranged from 10000 to 20000 individuals in recent years (Committee on Ungulate Management in Yellowstone National Park US National Research Council 2002). Nevertheless, such increases were proportionately large relative to past population size and occurred on very small annual ranges $\left(84-166 \mathrm{~km}^{2}\right)$ (Van Dyke

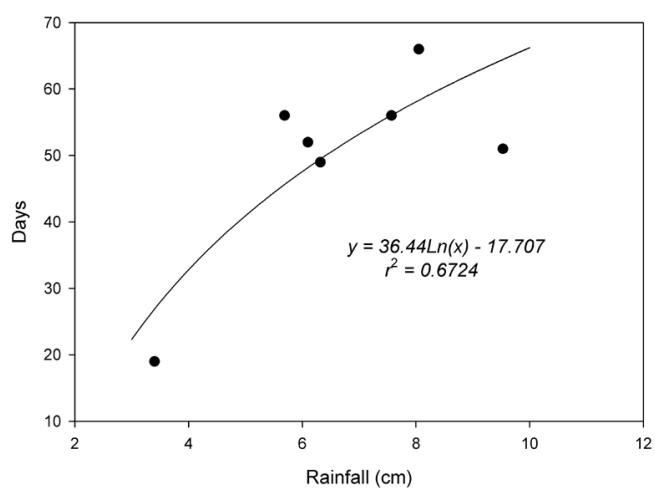

FIGURE 5. Relation between June and July rainfall (combined) and estimated number of days on non-traditional summer range in the Trout Creek and Wolf Creek dispersing groups in south-central Montana, USA, 1988-1991.

et al. 1998) compared to those of the Northern Yellowstone Population, whose annual range encompasses thousands of $\mathrm{km}^{2}$ (Committee on Ungulate Management in Yellowstone National Park U.S. National Research Council 2002). Thus, it is reasonable to believe that the numerical increases observed in these herds on these restricted ranges would increase densities and competition for space and other resources, contributing to the formation of dispersing groups, although the dispersive behavior seen in these small populations might be very different from that observed in larger populations.

\section{Size of home range and use and productivity of vegetation communities}

Variability in use and selection patterns of vegetation communities in different populations is, in part, evidence of the behavioral plasticity of Elk. As these populations experienced relatively large proportional increases, the movement and fidelity of colonists to new ranges appeared similar to observed seasonal movements of White-tailed Deer (Odocoileus virginianus) in areas fragmented by agriculture (Nixon et al. 1991). However, whereas deer occupied traditional vegetation communities in the new areas to which they dispersed, Elk in these dispersing groups demonstrated their plasticity in habitat selection by changing their patterns of use of vegetation communities as they moved to new ranges.

It is not only the proportion of a vegetation community in the landscape that determines its use by Elk, but also its juxtaposition and interspersion with other such communities (Porter and Church 1987), a dimension of availability that was beyond the scope of this study to measure. Thus, use of vegetation communities by specific populations would be a poor guide for landscape scale habitat management. In these populations Elk adjusted use of vegetation communities according to local and seasonal availabilities. 
Use of marginal habitats is associated with increased rates of range expansion in some ungulate species (Andersen et al. 2004). The larger home ranges of TC and WC groups using non-traditional lower elevation ranges in summer might indicate the same trend. Further, larger home ranges in these groups also suggested that forage on non-traditional ranges might have been more dispersed. However, comparisons of forage volume in core foraging areas of group and source populations did not support the premise that productivity was lower in ranges of dispersing groups. On the TC range, forage volume was higher in both graminoids and forbs. However, foraging areas for TC Elk were concentrated in riparian areas and probably could not support higher densities or more extended use by Elk in most years. Nutritional quality of vegetation is often better at higher elevations (Johnston et al. 1968; Boyce 1989), a trend confirmed on these ranges in measurements of protein and other nutrients in low vs. highelevation plants (Van Dyke et al. 1991; Van Dyke et al. 1994). However, McCorquodale (1991) found that, in sagebrush habitats used by Elk in central Washington similar to those used by the WC group, low intercommunity variability in forage production, lack of a nonforage overstory, and the relative abundance of foraging areas all mitigated against lower primary production.

The low-elevation, mostly treeless habitat of the WC group appeared to provide the greatest potential for heat stress of Elk during summer months because of its absence of thermal cover. However, Peek et al. (1982) have argued that thermal cover is not a requirement for Elk. Elk historically occurred on the Great Plains and in other areas that lacked thermal cover. Loss of Elk in these areas was due to human influence, not lack of adaptability to the habitat (Laliberte and Ripple 2004). In recent years Elk have recolonized areas in treeless, sagebrush-steppe habitats in central Washington (Rickard et al. 1977; McCorquodale et al. 1986; McCorquodale 1991) similar to those used by the WC Elk.

Both source populations and dispersing groups demonstrated fidelity to their selected home ranges from year to year. Such fidelity suggested that dispersing groups had already established some degree of tradition in their use of new ranges and were not dispersing randomly. However, early abandonment of non-traditional range at low elevations under drier conditions suggested that such new ranges might have been sub-optimal environments for Elk compared to traditional range. Dispersing groups responded to periods of environmental stress by rejoining source populations on traditional areas. By doing so, individuals in dispersing groups might have benefited from the source population's collective knowledge of available resources on traditional range and its successful, longterm strategies of range use (Edge et al. 1985).

\section{Management Implications}

Elk in dispersing groups demonstrated an ability to locate and adapt to non-traditional range through various combinations of altered habitat use, changes in patterns of seasonal elevational migration and adjustments in home range size and use. Given this repertoire of adaptive strategies, managers should assume that areas adjacent to existing Elk populations but presently without Elk could be colonized, and could be of importance to future growth of such populations and expansion of their range. For example, in restorations of Elk in Kentucky (USA), translocated Elk demonstrated fidelity to a variety of habitat types, including some not previously encountered on their original ranges (Larkin et al. 2004). Such considerations are of importance to managers as efforts to restore Elk populations in several U. S. states (Didier and Porter 1999; McClafferty and Parkhurst 2001; Larkin et al. 2004) are being considered or have commenced.

As noted previously, dispersing groups from these smaller populations might not exhibit the same patterns or behaviors associated with dispersal as has been observed in historically large herds. Thus, it would be advisable to consider and evaluate dispersive behavior associated with populations of different sizes before making broad generalizations about patterns of dispersive behavior that could apply to populations of all sizes. However, even with this caveat in hand, it will be true that expanding ranges and growing populations of Elk, regardless of size, might create added opportunity to view and hunt Elk, but such expansion could contribute to increasing conflict between Elk and other land uses such as agriculture and must be examined in a regional context. Where colonization of new range by Elk enhances the persistence of marginal populations and provides desired recreational opportunities for hunting and viewing Elk, managers should identify, provide access to, and, if possible, acquire adjacent range to which individuals might disperse, especially within the broader context of regional strategies that follow the principle of retaining large contiguous or connected areas that contain critical habitats (Dale et al. 2000). In these cases, dispersing groups should be protected from disturbance until they have established fidelity to new ranges (Larkin et al. 2004). Where dispersion to adjacent, but non-traditional ranges and habitats is likely to create or exacerbate land use conflicts between Elk and humans, managers should consider lowering densities of Elk on traditional range to reduce the likelihood of such dispersal.

\section{Acknowledgments}

R. J. Mackie and E. H. Merrill offered comments on earlier versions of this manuscript. S. H. Yoo assisted in preparation of text, tables, and figures. C. E. Eustace, Montana Department of Fish, Wildlife and Parks, provided logistical support for fieldwork. 


\section{Literature Cited}

Ackerman, B. B., F. A. Leban, M. D. Samuel, and E. O. Garton. 1990. User's manual for program HOMERANGE. Second edition. Technical Report 15, Forestry, Wildlife, and Range Experiment Station, University of Idaho, Moscow, Idaho, USA.

Andersen, R., I. Herfindel, B. E. Sæther, J. D. C. Linnell, J. Oddén, and O. Liberg. 2004. When range expansion is faster in marginal habitats. Oikos 107: 210-214.

Boyce, M. S. 1989. The Jackson Elk population: intensive wildlife management in North America. Cambridge University Press, Cambridge, UK.

Charnov, E. L. 1976. Optimal foraging: the marginal value theorem. Theoretical Population Biology 9: 129-136.

Clutton-Brock, T. H., M. Major, and F. E. Guinness. 1985. Population regulation in male and female red deer. Journal of Animal Ecology 54: 831-846.

Committee on Ungulate Management in Yellowstone National Park. US National Research Council. 2002. Ecological dynamics on Yellowstone's northern range. National Academy Press, Washington, DC.

Craighead, J. J., F. C. Craighead, Jr., R. L. Ruff, and B. W. O'Gara. 1973. Home-ranges and activity patterns of nonmigratory Elk of the Madison Drainage population as determined by biotelemetry. Wildlife Monographs 33 .

Dale, V. H., S. Brown, R. A. Haeuber, N. T. Hobbs, N. Huntly, R. J. Naiman, W. E. Riebsame, M. G. Turner, and T. J. Valone. 2000. Ecological principles and guidelines for managing the use of land. Ecological Applications 10: 639-670.

Didier, K. A., and W. F. Porter. 1999. Large-scale assessment of potential habitat to restore Elk to New York state. Wildlife Society Bulletin 27: 409-418.

Dixon, K. R., and J. A. Chapman. 1980. Harmonic mean measure of animal activity areas. Ecology 61: 1040-1044.

Edge, W. D., C. L. Marcum, and S. L. Olsen. 1985. Effects of logging on home-range fidelity of Elk. Journal of Wildlife Management 49: 741-744.

Fretwell, S. D., and H. L. Lucas. 1970. On territorial behavior and other factors influencing habitat distribution in birds. I. Theoretical Development. Acta Biotheoretica 19: 16-36.

Johnston, A., L. M. Beseau, and S. Smoliak. 1968. Chemical composition and in vitro digestibility of alpine tundra plants. Journal of Wildlife Management 32: 774-777.

Kaufman, J. H. 1962. Ecology and social behavior of the coati, Nasua narica on Barro Colorado Island, Panama. University of California Publications in Zoology 60: 95-222.

Laliberte, A. S., and W. J. Ripple. 2004. Range contractions of North American carnivores and ungulates. BioScience 54: 123-128.

Larkin, J. L., J. J. Cox, M. W. Wichrowski, M. R. Dzialak, and D. S. Maehr. 2004. Influences on release-site fidelity of translocated Elk. Restoration Ecology 12: 97-105.

Manly, B. F., L.L. McDonald, D. L. Thomas, T. L. McDonald, and W. P. Erickson. 2002. Resource selection by animals: statistical design and analysis for field studies. $2^{\text {nd }}$ edition. Kluwer Academic Publishers, Dordrecht, The Netherlands.

McClafferty, J. A., and J. A. Parkhurst. 2001. Using public surveys and Geographic Information Systems to determine the feasibility of restoring Elk to Virginia. Pages 83-98 in Large mammal restoration: ecological and sociological challenges in the 21 st century. Edited by D. S. Maehr, R. Noss, and J. L. Larkin. Island Press, Washington, DC.

McCorquodale, S. M. 1991. Energetic considerations and habitat quality for Elk in arid grasslands and coniferous forests. Journal of Wildlife Management 55: 237-242.
McCorquodale, S. M., K. F. Raedeke, and R. D. Taber. 1986. Elk habitat use patterns in shrub-steppe of Washington. Journal of Wildlife Management 50: 664-669.

Mielke, P. W., K. J. Berry, and E. S. Johnson. 1976. Multi-response permutation procedures for a priori classifications. Communications in Statistics: Theory and Methods 5: 1409-1424.

NOAA (National Oceanic and Atmospheric Administration). 1992. Annual climatological survey. National Climatic Data Center, Asheville, North Carolina, USA.

Nielson, A. E., and W. M. Shaw. 1967. A helicopter-dart gun technique for capturing moose. Proceedings of the Annual Conference of the Western Association of State Fish and Game Commissioners 47: 183-199.

Nixon, C. M., P. P. Hansen, P. A. Brewer, and J. E. Chelsvig. 1991. Ecology of white-tailed deer in an intensively farmed region of Illinois. Wildlife Monographs 118: 1-77.

Parker, G. A., and R. A. Stuart. 1976. Animal behavior as a strategy optimizer: evolution of resource assessment strata and optimal emigration thresholds. American Naturalist 110: 1055-1076.

Peek, J. M., M. D. Scott, L. J. Nelson, D. J. Pierce, and L. L. Irwin. 1982. Role of cover in habitat management for big game in northwestern United States. Transactions of the North American Wildlife and Natural Resources Conference 47: 363-373.

Porter, W. F, and K. E. Church. 1987. Effects of environmental pattern on habitat preference analysis. Journal of Wildlife Management 51: 681-685.

Rickard, W. H., J. D. Hedlund, and R. E. Fitzner. 1977. Elk in the shrub-steppe region of Washington: an authentic record. Science 196: 1009-1010.

Rosenzweig, M. L. 1991. Habitat selection and population interactions: the search for mechanism. American Naturalist 137: S5-S28.

Safriel, U. N., and U. Ritte. 1983. Universal correlates of colonizing ability. Pages 215-239 in The ecology of animal movement. Edited by I. R. Swingland and P. J. Greenwood. Clarendon Press, Oxford, UK.

Samuel, M. D., D. J. Pierce, and E. O. Garton. 1985. Identifying areas of concentrated use within the home range. Journal of Animal Ecology 54: 711-719.

Van Dyke, F. G., J. P. Dibenedetto, and S. C. Thomas. 1991. Vegetation and Elk response to prescribed burning in south-central Montana. Pages 163-179 in The Greater Yellowstone Ecosystem: redefining America's wilderness heritage. Edited by R. B. Keiter and M. S. Boyce. Yale University Press, New Haven, Connecticut, USA.

Van Dyke, F. G., and W. C. Klein. 1996. Response of Elk to installation of oil wells. Journal of Mammalogy 77: 10281041.

Van Dyke, F. G., B. L. Probert, and J. J. Rozema. 1994. Vegetation characteristics of Elk summer range in southcentral Montana. Pages 285-300 in Plants and their environments. Proceedings of the first biennial scientific conference on the Greater Yellowstone Ecosystem. Edited by D. L. Despain. NPS/NRYELL/NTTR-93/XX.

Van Dyke, F. G., B. L. Probert, and G. M. Van Beek. 1995. Moose home range fidelity and core area characteristics in south-central Montana. Alces 31: 93-104.

Van Dyke, F. G. W. C. Klein, and S. T. Stewart. 1998. Longterm range fidelity in Rocky Mountain Elk. Journal of Wildlife Management 62: 1020-1035.

Received 31 March 2006

Accepted 9 May 2008 